\title{
PEMETAAN BAHAYA BANJIR LAHAN SAWAH DI KABUPATEN KARAWANG
}

\section{Flood Hazard Mapping Level Paddy Field at District Karawang}

\author{
Tommi ${ }^{1)^{*}}$, Baba Barus ${ }^{2}$ dan Arya Hadi Dharmawan ${ }^{3)}$ \\ 1) Alumni Program Studi Ilmu Perencanaan Pembangunan Wilayah dan Perdesaan, Sekolah Pascasarjana IPB, \\ Kampus IPB Dramaga, Bogor 16680 \\ 2) Departemen Ilmu Tanah dan Sumberdaya Lahan, Fakultas Pertanian IPB, J1. Meranti Kampus IPB Dramaga, \\ Bogor 16680 \\ 3) Departemen Sains dan Komunikasi Pengembangan Masyarakat, Fakultas Ekologi Manusia IPB, Jl. Kamper \\ Kampus IPB Darmaga Bogor 16680
}

\begin{abstract}
Flooding is one of the natural disasters that frequently hit several countries, including Indonesia. Data from the BNPB show of the year 1815 - 2013 ranks first flood disaster events most of the other disasters that as many as 5,394 events. Karawang District was ranked $3^{\text {rd }}$ highest number of flood events in West Java. Nationally data from BNPB show Karawang ranks 8th flood-prone area. The purpose of this study to analyze the level of hazard of flooding the paddy field in Karawang. The method used in analyzing the level of hazard of flooding is done by overlaying and scoring from the paddy fields map, rainfall maps, soil drainage maps, and flood events maps. The results of this study indicate the paddy field in Karawang District which has a high flood hazard level contained in the Telukjambe West, East Telukjambe, and Jayakerta Sub Disctrict.
\end{abstract}

Keywords: Hazard, flood, mapping

\section{ABSTRAK}

Kabupaten Karawang merupakan salah satu daerah yang sering terkena banjir berdasarkan data dari BNPB dari tahun 1815 - 2013 jumlah kejadian banjir di Kabupaten Karawang berada pada urutan ke-3 terbanyak. Banjir di Kabupaten Karawang membawa kerugian yang besar bagi petani, maka dari itu pemetaan tingkat bahaya banjir sangat diperlukan. Kabupaten Karawang berada pada urutan ke-3 jumlah kejadian banjir terbanyak di Jawa Barat. Secara nasional data dari BNPB menunjukkan Kabupaten Karawang menempati urutan ke-8 wilayah rawan bencana banjir. Tujuan dari penelitian ini menganalisis tingkat bahaya banjir lahan sawah di Kabupaten Karawang. Metode yang digunakan dalam menganalisis tingkat bahaya banjir dilakukan dengan overlay dan skoring dari peta sawah, peta curah hujan, peta drainase tanah, dan peta kejadian banjir. Hasil dari penelitian ini menunjukkan lahan sawah di Kabupaten Karawang yang memiliki tingkat bahaya banjir tinggi terdapat di Kecamatan Telukjambe Barat, Telukjambe Timur, dan Jayakerta.

Kata kunci: Bahaya, banjir, pemetaan

\section{PENDAHULUAN}

Banjir merupakan salah satu peristiwa bencana alam yang sering melanda sejumlah negara termasuk Indonesia. Data dari BNPB menunjukkan dari tahun 1815 2013 banjir menempati urutan pertama kejadian bencana terbanyak dari bencana lainnya yaitu sebanyak 5,394 kejadian. Banjir adalah peristiwa atau keadaan dimana terendamnya suatu daerah atau daratan karena volume air yang meningkat. Banjir dapat disebabkan oleh perubahan iklim, peningkatan frekuensi dan intensitas curah hujan yang tinggi atau akibat banjir kiriman dari daerah lain yang berada di tempat lebih tinggi (Hapsoro dan Buchori, 2015).

Wilayah Jawa Barat memiliki curah hujan yang tinggi dengan intensitas $300-400 \mathrm{~mm} \mathrm{bulan}^{-1}$. Kondisi ini menyebabkan beberapa wilayah sering terkena banjir. (Estiningtyas, 2009) Kemungkinan yang terjadi akibat curah hujan yang tinggi tersebut adalah meluapnya air di sepanjang Daerah Aliran Sungai (DAS). Keadaan ini dapat menjadi semakin parah karena ekosistem suatu daerah itu rusak sehingga terjadi pendangkalan dan penyempitan aliran sungai (Indrianawati et al., 2013)
Salah satu daerah di Jawa Barat yang sering terkena banjir adalah Kabupaten Karawang. Berdasarkan data dari Badan Nasional Penanggulangan Bencana (BNPB) sejak tahun 1815 - 2013 Kabupaten Karawang berada pada urutan ke-3 jumlah kejadian banjir terbanyak di Jawa Barat. Secara nasional data dari BNPB menunjukkan Kabupaten Karawang menempati urutan ke-8 wilayah rawan bencana banjir.

Banjir di Kabupaten Karawang selain disebabkan curah hujan yang tinggi juga disebabkan oleh kondisi hulu DAS Citarum yang buruk. Kondisi hulu DAS Citarum yang buruk dapat terlihat dari berkurangnya fungsi kawasan lindung (hutan dan non hutan), berkembangnya kawasan permukiman tanpa perencanaan yang baik, budidaya pertanian yang tidak sesuai dengan kaidah konservasi. Kondisi ini menyebabkan alur Sungai Citarum di Karawang tidak mampu lagi menampung debit banjir dari hulu, sehingga terjadi banjir.(Imansyah, 2012).

Ancaman banjir di Kabupaten Karawang perlu diwaspadai karena Kabupaten Karawang merupakan salah satu daerah yang memberikan kontribusi bagi kebutuhan beras nasional rata-rata mencapai 865,000 ton beras tahun ${ }^{-1}$ 
(Distanhut Kabupaten Karawang, 2015). Adanya banjir pada lahan sawah dapat menyebabkan berkurangnya luas panen dan produksi beras (Hartini et al., 2015) sehingga menggangu kestabilan cadangan bahan makanan pokok nasional (Suprapto, 2011).

Seperti dalam lima tahun terakhir, banjir hampir selalu menyebabkan banyak sawah yang gagal panen. Kegagalan panen tertinggi terjadi pada musim tanam tahun 2013/2014 dengan luas total puso 7,700 ha sawah (Distanhut Kabupaten Karawang, 2015). Kondisi ini tentu sangat mempengaruhi produksi pangan di wilayah tersebut.

Produktivitas padi rata - rata Kabupaten Karawang yang mencapai 6 ton ha $^{-1}$ dan produksi padi rata - rata per tahun mencapai $1,100,000$ ton tentunya banjir akan menyebabkan ancaman penurunan produksi sebesar 46,200 ton. Mengingat banjir cukup mengancam produksi padi di Kabupaten Karawang maka pemetaan tingkat bahaya banjir sangat perlu dilakukan agar didapatkan data dan informasi yang menggambarkan tingkat bahaya banjir sehingga dapat menyusun rekomendasi penanganan banjir khususnya lahan sawah di Kabupaten Karawang. Selain itu peta bahaya banjir dapat digunakan sebagai dasar dalam melakukan perencanaan tata ruang di daerah tersebut (Wahyuni dan Suroso, 2016). Penelitian - penelitian sebelumnya mengenai tingkat bahaya banjir sudah banyak seperti yang dilakukan oleh Hartini et al. (2015); Satriawan (2010); dan Hariyani et al. (2012). Namun, penelitian tingkat bahaya banjir lahan sawah khususnya belum pernah dilakukan maka dari itu pada penelitian ini akan dilakukan pemetaan tingkat bahaya banjir lahan sawah di Kabupaten Karawang.

\section{BAHAN DAN METODE}

Penelitian ini dilaksanakan di Kabupaten Karawang Jawa Barat dari bulan Agustus-Desember 2015. Lokasi penelitian dilakukan pada seluruh sawah di Kabupaten Karawang yang dialiri Sungai Citarum. Lokasi Penelitian terdapat pada Gambar 1 dan Gambar 2.

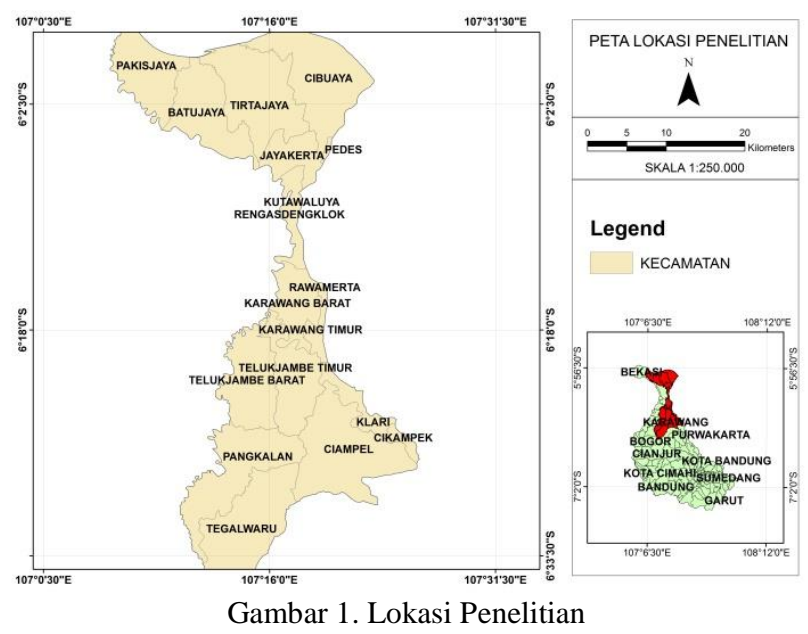

Bahan yang digunakan dalam penelitian ini adalah peta administrasi DAS Citarum skala 1:250,000; peta RBI skala 1:25,000, peta tutupan lahan BPDAS tahun 2013, peta satuan lahan skala 1:250,000, data curah hujan tahun 20092014 dari Dinas PSDA Jabar, dan data kejadian banjir musim tanam 2008/2009-2013/2014 yaitu berupa tinggi genangan, lama genangan, dan frekuensi banjir. Peralatan yang digunakan dalam penelitian ini adalah kuesioner dan seperangkat komputer yang dilengkapi dengan software ArcGIS dan Microsoft Excel.

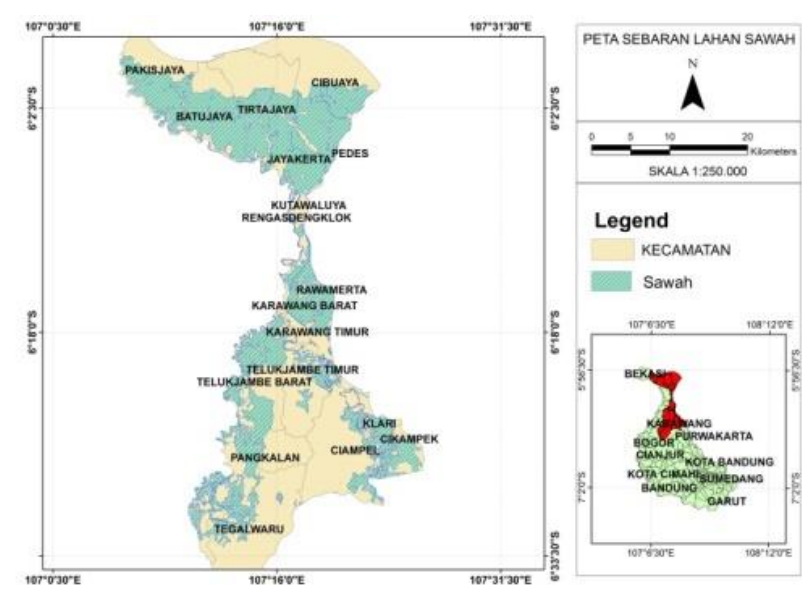

Gambar 2. Peta sebaran sawah

\section{Analisis Tingkat Bahaya Banjir}

Tingkat bahaya (kerawanan) suatu bencana disusun berdasarkan dua komponen utama, yaitu kemungkinan terjadi suatu ancaman dan besaran dampak yang pernah tercatat untuk bencana yang terjadi tersebut. Dapat dikatakan bahwa indeks bahaya banjir disusun berdasarkan data dan catatan sejarah kejadian yang pernah terjadi pada suatu daerah (Sujatmoko et al., 2015).

Analisis tingkat bahaya banjir dalam penelitian ini merupakan gabungan dari parameter bahaya banjir yang dilakukan dalam penelitian Hariyani et al. (2012) dengan Balittanah (2005). Parameter yang digunakan dalam analisis tingkat bahaya banjir lahan sawah adalah curah hujan, drainase tanah, dan data kejadian banjir di lahan sawah yang terdiri dari frekuensi banjir, tinggi genangan, dan lama genangan.

Analisis dilakukan dengan menjumlahkan skor dari masing - masing parameter sesuai dengan kriteria yang terdapat pada Tabel 1 .

Tabel 1. Skor dan parameter tingkat bahaya banjir

\begin{tabular}{|c|c|c|c|}
\hline Parameter & Nilai & Skor & $\begin{array}{c}\text { Tingkat Bahaya } \\
\text { Banjir }\end{array}$ \\
\hline \multirow{3}{*}{ Curah Hujan (mm) } & $1500-2000$ & 1 & Rendah \\
\hline & $2000-2500$ & 2 & Sedang \\
\hline & $>2500$ & 3 & Tinggi \\
\hline \multirow{3}{*}{ Drainase Tanah } & Baik/Cepat & 1 & Rendah \\
\hline & $\begin{array}{c}\text { Sedang/Agak } \\
\text { terhambat }\end{array}$ & 2 & Sedang \\
\hline & $\begin{array}{c}\text { Terhambat/Sangat } \\
\text { terhambat }\end{array}$ & 3 & Tinggi \\
\hline \multirow{3}{*}{$\begin{array}{l}\text { Frekuensi Banjir } \\
\text { (dalam } 5 \text { tahun } \\
\text { terakhir) }\end{array}$} & $0-1$ kali & 1 & Rendah \\
\hline & $2-3$ kali & 2 & Sedang \\
\hline & $4-5$ kali & 3 & Tinggi \\
\hline \multirow{3}{*}{$\begin{array}{c}\text { Tinggi Genangan Rata } \\
\text { - Rata (dalam } 5 \text { tahun } \\
\text { terakhir) }\end{array}$} & $0-35 \mathrm{~cm}$ & 1 & Rendah \\
\hline & $36-70 \mathrm{~cm}$ & 2 & Sedang \\
\hline & $>70 \mathrm{~cm}$ & 3 & Tinggi \\
\hline \multirow{3}{*}{$\begin{array}{c}\text { Lama Genangan Rata } \\
\text { - Rata (dalam } 5 \text { tahun } \\
\text { terakhir) }\end{array}$} & $0-3$ hari & 1 & Rendah \\
\hline & $3-7$ hari & 2 & Sedang \\
\hline & $>7$ hari & 3 & Tinggi \\
\hline
\end{tabular}


Setelah nilai indeks bahaya banjir didapatkan maka akan didapatkan juga sebaran tingkat bahaya banjir untuk lahan sawah di Kabupaten Karawang yang disajikan dalam peta tingkat bahaya banjir lahan sawah Kabupaten Karawang.

'Peta yang dihasilkan dari analisis ini akan menggambarkan sebaran klas tingkat bahaya banjir lahan sawah di Kabupaten Karawang. Adanya peta ini dapat memberikan informasi kepada pemerintah dan pengambil kebijakan khususnya dalam memprioritaskan daerah mana saja yang harus ditangani ketika terjadi banjir. Tahapan analisis ini dapat dilihat pada Gambar 3.

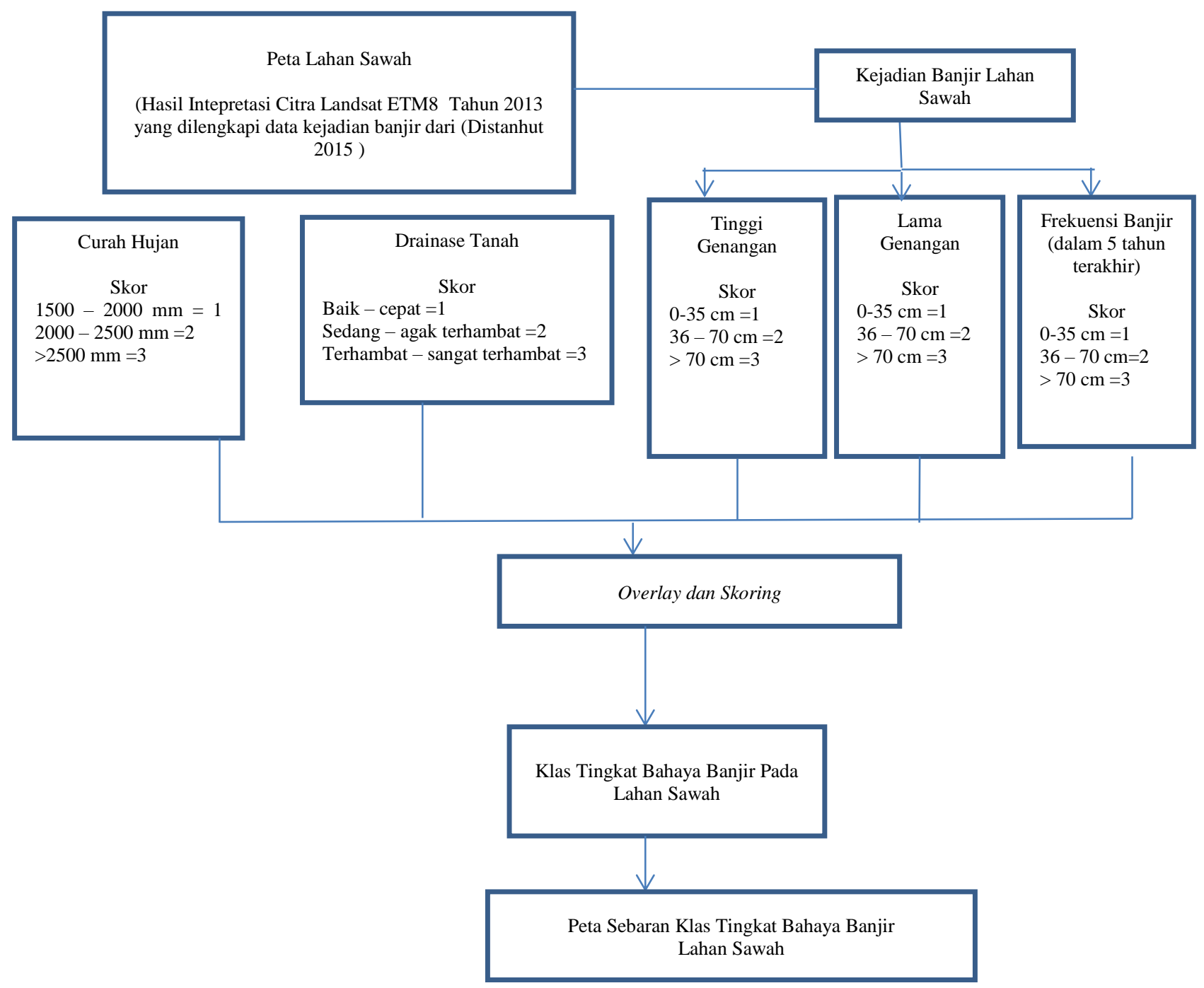

Gambar 3. Tahapan analisis

\section{HASIL DAN PEMBAHASAN}

Curah hujan yang terdapat di Kabupaten Karawang terbagi menjadi 4 kelas yaitu 1,500 - 2,000 mm; $2,000-2,500 \mathrm{~mm} ; 2,500-3,000 \mathrm{~mm}$; dan 3,000 - 3,500 $\mathrm{mm}$. Sebaran kelas curah hujan didominasi oleh kelas 1,500 $-2,000 \mathrm{~mm}$. Kelas yang mendominasi berikutnya adalah kelas 2,000-2,500 mm; 2,500-3,000 mm, dan yang paling sedikit luasannya adalah kelas 3,000 - 3,500 mm. Data tersebut menunjukan bahwa secara keseluruhan curah hujan di Kabupaten Karawang berada pada kelas intensitas yang rendah.

Kelas drainase tanah untuk lahan sawah di Kabupaten Karawang berdasarkan sifat tanahnya terbagi menjadi 5 kelas. Kelas tersebut adalah terhambat, agak terhambat, sedang, baik, dan cepat. Kelas drainase tanah yang sebarannya yang paling mendominasi di Kabupaten
Karawang adalah kelas terhambat. berikutnya adalah kelas sedang. Kelas yang lainnya sebarannya tidak terlalu dominan dan kelas yang paling sedikit adalah kelas cepat. Kelas drainase terhambat merupakan kelas yang paling luas dengan luasan 24,482 ha hampir $70 \%$. Kelas drainase berikutnya yang juga cukup luas adalah $7,737.87$ ha $(22 \%)$ dan yang paling sedikit luasannya adalah kelas drainase cepat 149.55 ha atau $0.43 \%$.

Berdasarkan data yang diperoleh dari Dinas Pertanian Kabupaten Karawang data historis yang diperoleh adalah frekuensi banjir dalam 5 tahun terakhir, tinggi genangan, dan lama genangan. Data historis banjir untuk lahan sawah di setiap Kecamatan yang dialiri DAS Citarum dapat dilihat pada Tabel 2. Data pada Tabel 2 menunjukkan frekuensi banjir di lahan sawah Kabupaten Karawang selama 5 tahun yang paling banyak adalah 4 kali kejadian. Wilayah tersebut adalah Kecamatan Jayakerta, Pakisjaya, Rawamerta, Telukjambe Barat, Telukjambe Timur, dan 
Tirtajaya. Selain itu, ada juga wilayah yang 5 kali mengalami kejadian banjir selama 5 tahun atau setiap tahun mengalami banjir wilayah tersebut adalah Kecamatan Batujaya dan Pedes. Namun, ada juga wilayah yang tidak pernah banjir yaitu Kecamatan Tegalwaru.

Tinggi genangan banjir pada lahan sawah di Kabupaten Karawang terbagi ke dalam 5 kelas. Kelas yang paling tinggi genangannya adalah kelas $121-150 \mathrm{~cm}$. Wilayah yang berada pada kelas tersebut adalah Kecamatan Ciampel, Pangkalan, dan Telukjambe Barat. Kelas yang paling rendah adalah kelas $0-30$, wilayah yang termasuk dalam kelas tersebut adalah Kecamatan Tegalwaru. Wilayah tersebut berada pada kelas yang rendah karena tidak pernah terkena banjir.

Lama genangan menunjukkan hampir seluruh sawah di wilayah Kabupaten Karawang lama tergenang Kelas mendominasi ketika banjir. Hampir di seluruh wilayah Kabupaten Karawang lama genangannya $>7$ hari. Wilayah dengan lama genangan $>7$ hari terdapat di 11 kecamatan.

Tabel 2. Data kejadian banjir lahan sawah Kabupaten Karawang

\begin{tabular}{lccc}
\hline \multicolumn{1}{c}{ Kecamatan } & $\begin{array}{c}\text { Frekuensi } \\
\text { Banjir } \\
\text { (5 tahun } \\
\text { terakhir) }\end{array}$ & $\begin{array}{c}\text { Lama } \\
\text { Genangan } \\
\text { (hari) }\end{array}$ & $\begin{array}{c}\text { Tinggi } \\
\text { Genangan } \\
(\mathrm{cm})\end{array}$ \\
\hline Batujaya & 5 & 16 & 60 \\
Ciampel & 3 & 10 & 150 \\
Cibuaya & 3 & 16 & 50 \\
Cikampek & 1 & 6 & 60 \\
Jayakerta & 4 & 16 & 80 \\
Karawang Barat & 2 & 15 & 100 \\
Karawang Timur & 2 & 15 & 100 \\
Klari & 2 & 5 & 100 \\
Pakisjaya & 4 & 16 & 70 \\
Pangkalan & 2 & 5 & 150 \\
Pedes & 5 & 16 & 60 \\
Rawamerta & 4 & 15 & 70 \\
Rengasdengklok & 1 & 7 & 70 \\
Tegalwaru & 0 & 15 & 150 \\
Telukjambe Barat & 4 & 15 & 100 \\
Telukjambe Timur & 4 & 16 & 65 \\
Tirtajaya & 1 & & \\
\hline Sumber: Distanhut Kabupaten Karawang, 2015 & & &
\end{tabular}

Tingkat bahaya banjir yang didapatkan dalam penelitian ini yang disajikan pada Gambar 2 menunjukkan secara keseluruhan sawah - sawah di Kabupaten Karawang yang dialiri Sungai Citarum berada tingkat bahaya sedang. Namun, ada juga wilayah yang berada pada tingkat bahaya tinggi. Wilayah tersebut adalah Kecamatan Telukjambe Barat, Jayakerta, dan Telukjambe Timur. Wilayah yang berada pada tingkat bahaya banjir rendah terdapat di Kecamatan Tegalwaru. Secara umum peta tingkat bahaya banjir yang dihasilkan dalam penelitian ini hampir sama dengan peta tingkat bahaya banjir dari BNPB tahun 2010. Peta tingkat bahaya banjir dari BNPB tahun 2010 memperlihatkan bahwa tingkat bahaya banjir Kabupaten Karawang secara keseluruhan pada tahun 2010 berada pada tingkat sedang

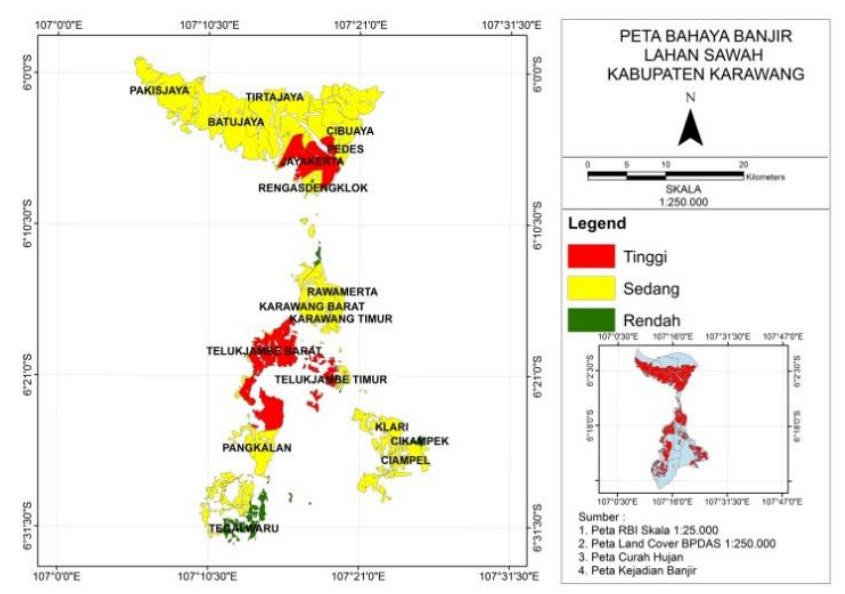

Gambar 4. Sebaran klas tingkat bahaya banjir lahan sawah Kabupaten Karawang

Wilayah dengan tingkat bahaya banjir tinggi umumnya banyak dipengaruhi oleh kelas drainase tanah dimana rata - rata kelas drainase tanahnya adalah terhambat. Tingkat bahaya banjir yang tinggi juga dipengaruhi sejarah (historis) kejadian banjir di wilayah tersebut pada tahun - tahun sebelumnya. Wilayah tersebut umumnya selama 5 tahun terakhir banjir hampir selalu terjadi setiap tahun kemudian tinggi genangan saat terjadi banjir juga termasuk tinggi lebih dari $70 \mathrm{~cm}$ kemudian dari lama genangan saat banjir juga termasuk lama lebih dari 7 hari.

Drainase tanah di lahan sawah Kabupaten Karawang yang terhambat disebabkan oleh tekstur tanah di wilayah tersebut yang tergolong halus. Sehingga air mudah tergenang dan sulit keluar. Hal ini sesuai dengan pendapat Hartini et al. (2015) bahwa faktor yang berpengaruh utama kerawanan banjir lahan sawah adalah topografi yang datar, elevasi yang rendah dan jenis tanah dengan tekstur halus. Wilayah dengan tingkat bahaya banjir tinggi di Kecamatan Jayakerta yang terletak di bagian utara memiliki karakteristik dekat dengan daerah pantai sehingga ketinggian tempat di wilayah tersebut cukup rendah. Kondisi ini membuat wilayah ini sering terkena banjir. Wilayah dengan tingkat bahaya banjir tinggi lainnya di Kecamatan Telukjambe Barat dan Kecamatan Telukjambe Timur memiliki karakteristik dekat dengan daerah industri dan perkotaan. Di wilayah ini sudah banyak sekali konversi lahan pertanian menjadi lahan industri dan pemukiman. Kondisi ini menyebabkan limpasan permukaan yang tinggi sehingga Sungai Citarum mudah meluap dan menyebabkan banjir di wilayah tersebut.

Wilayah dengan bahaya banjir tinggi di Kabupaten Karawang tidak berada pada daerah dengan curah hujan tinggi. Hal ini sama dengan penelitian Ozkan dan Tarhan (2016) daerah dengan tingkat bahaya banjir tinggi tidak berada pada wilayah dengan curah tinggi. Namun faktor lain seperti penggunaan lahan, topografi dan elevasi juga mempengaruhi bahaya banjir di wilayah tersebut.

\section{SIMPULAN}

Tingkat bahaya banjir untuk lahan sawah di Kabupaten Karawang yang berada di aliran DAS Citarum secara umum berada pada tingkat bahaya sedang. Namun, ada daerah yang memiliki tingkat bahaya banjir yang tinggi 
yaitu Kecamatan Telukjambe Barat, Telukjambe Timur, dan Jayakerta.

\section{DAFTAR PUSTAKA}

[Balittanah] Balai Penelitian Tanah Kementerian Pertanian. 2005. Peta digital lahan sawah rawan kekeringan dan banjir penting untuk crop modeling. Balittanah, Bogor.

[BNPB] Badan Nasional Penanggulangan Bencana. 2010. Peta Indeks Bahaya Banjir Indonesia. BNPB, Jakarta.

2012. Data Bencana Banjir Indonesia Tahun 1815- 2013. BNPB, Jakarta.

[Distanhut Kabupaten Karawang] Dinas Pertanian, Kehutanan, Perkebunan dan Peternakan Kabupaten Karawang. 2015. Data Produksi dan Produktivitas Padi Sawah 2006 - 2013. Distanhut, Karawang.

Estiningtyas, W., R. Boer dan B. Agus. 2013. Analisis hubungan curah hujan dengan kejadian banjir dan kekeringan pada wilayah dengan sistim usahatani berbasis padi di Propinsi Jawa Barat. J. Agromet., 23: $11-19$

Hapsoro, A.W. dan I. Buchori. 2015. Kajian kerentanan sosial dan ekonomi terhadap bencana banjir. Jurnal Teknik PWK, 4: 542-553.

Hariyani, N.S., A. Zubaidah, D. Dirgahayu, H.F. Yulianto dan J. Pasaribu. 2012. Model bahaya banjir menggunakan data penginderaan jauh di Kabupaten Sampang. Jurnal Penginderaan Jauh, 9: 52-66.

Hartini, S., M.P. Hadi, Sudibyakto dan A. Poniman. 2015. Risiko banjir pada lahan sawah di Semarang dan sekitarnya. Majalah Ilmiah Globe, 17:051 - 058.

Indrianawati, D.M. Hakim dan A. Deliar. 2013. Penyusunan basis data untuk identifikasi daerah rawan banjir dikaitkan dengan infrastruktur data spasial studi kasus: Provinsi Jawa Barat. Jurnal Itenas Rekayasa, 17: 22-31.

Ozkan, S.P. dan C. Tarhan. 2016. Detection of flood hazard in urban areas using GIS: izmir case. Procedia Technology, 22:373 - 381.

Satriawan, H. 2010. Evaluasi tingkat bahaya banjir dan erosi serta strategi penanggulangannya di Kabupaten Nagan Raya. Lentera, 10: 78-85.

Sujatmoko, B., Y. Andestian, Rinaldi dan A. Hendri. 2015. Pembuatan peta indeks resiko banjir pada kawasan drainase Kecamatan Sukajadi Kota Pekanbaru. Annual Civil Engineering Seminar Pekanbaru.

Suprapto. 2011. Statistik pemodelan bencana banjir Indonesia (Kejadian 2002-2010). Jurnal BNPB, 2: $32-47$.

Wahyuni, H. dan D.J.A. Suroso. 2016. Kajian pemanfaatan peta bahaya banjir dalam perencanaan tata ruang wilayah Kabupaten Bojonegoro tahun 2011-2031. Jurnal PWK, 5: 109-117 